\title{
Grammatiline sugu - tõlkija sõber või vaenlane?
}

Sirje Kupp-Sazonov

doi:10.7592/PS/28-4kupp_sazonov

Teesid: Käesoleva artikli eesmärk on peatuda mõningatel tõlkeraskustel, mis on tingitud sellest, et vene keeles eksisteerib grammatilise soo kategooria ja eesti keeles see puudub. Probleemsed kontekstid võib jagada kolme gruppi: 1) venekeelsed он/она ja eestikeelne tema; 2) venekeelsed он/она ja eestikeelne see; 3) isikuid tähistavad nimisõnad.

Ka eesti keeles on mõned vahendid, mis grammatilise soo kategooria puudumist kompenseerivad, näiteks:

1) sufiksid: -nna (kuninganna), -tar (krahvitar);

2) eesliide nais- (naissportlane);

3) liitsõnad, milles üks sõna viitab isiku soole (kasuõde ja kasuvend).

Eraldi teemana on vaatluse all sõnad, millel juba originaalis on lisaks soo märkimisele ka eesmärk väljendada negatiivset hinnangut.

Märksõnad: grammatiline sugu, eesti keel, vene keel, tõlkimine, asesõnad, nimisõnad.

\section{Sissejuhatus}

Grammatiliste raskuste ja sellest tulenevalt transformatsioonide teema on tõlketeoorias ning -praktikas viimastel aastatel muutunud aina olulisemaks. Üheks põhjuseks võib pidada seda, et nii keeleteadlased kui ka tõlkespetsialistid on jõudnud järeldusele, 
et grammatika ei ole lihtsalt rangete ja igavate keelereeglite ning -normide kogum, vaid tegelikkuses võimaldab grammatika samasugust loomingulist lähenemist keelele nagu leksika (Remtšukova 2005: 23). Teisest küljest on selge - mida olulisemad erinevused on kahe keele grammatiliste süsteemide vahel, seda suuremate väljakutsetega peab tõlkija kokku puutuma. A. Lange on kirjutanud: "Tõlkimine tähendab muu hulgas ühe keele grammatika väljavahetamist teise keele grammatika vastu, ja kalkuleerida saab siin vähe" (Lange 2008: 23). Vene ja eesti keel on oma grammatika poolest vägagi erinevad, näiteks käänete arv (eesti $k$ neliteist ja vene $\mathrm{k}$ kuus), ajavormide süsteem (eesti k neli ajavormi, millest kolm on mineviku vormid ning puudub grammatiline tuleviku vorm, vene $\mathrm{k}$ kolm) jne.

Käesolevas artiklis keskendutakse mõningatele tõlkeraskustele, mis on tingitud vene keeles olemas olevast grammatilise soo kategooriast, samal ajal kui eesti keeles see puudub. Tõlke seisukohast on sageli oluline ja ühtlasi ka kõige keerulisem anda edasi just elusolendite soolist kuuluvust, elutute objektide puhul mängib grammatiline sugu tõlkes tunduvalt väiksemat rolli, vähemalt mis puudutab vene-eesti tõlget. Kuid mitmed eksperimendid on näidanud, et grammatiline sugu võib kujundada kõnelejate tundeid ja assotsiatsioone neid ümbritsevate objektide suhtes, nagu on kirjutanud mh nt iisraeli keeleteadlane Guy Deutscher. 1990. aastatel olevat psühholoogid, kes võrdlesid hispaania ja saksa keeles sõnu, mis ühes keeles olid vastavalt nais- ja teises meessoost, leidnud, et inimesed kirjeldasid objekte vastavalt nende soole. Näiteks sõna sild, mis on hispaania keeles meessoost el puente, oli hispaanlaste jaoks tugev, sakslaste die Brücke aga elegantne ja sale (Deutscher 2010).

Materjali analüüsist selgub, et peamised takistused tõlkimisel tekivad kolmel juhul:

1) venekeelsed asesõnad он/она ja eestikeelne tema;

2) venekeelsed asesõnad он/она ja eestikeelne see;

3) mitmesuguseid isikuid ja ameteid tähistavad nimisõnad.

Näited pärinevad vene ilukirjanduslikest tekstidest ja nende tõlgetest eesti keelde. Enne analüüsi oleks aga kohane vaadata põgusalt üle peamised seisukohad grammatilise soo osas vene keeles. 


\section{Grammatiline sugu vene keeles}

Sookategoorial on vene keeles keskne koht nimisõna grammatilises süsteemis ja seda kahel põhjusel. Esiteks - grammatiline sugu määrab ära omadus-, tegu- ja asesõnade ühildumise nimisõnaga. Teiseks - just grammatilise soo alusel jagunevad nimisõnad käändkondadesse.

Seetõttu kuuluvad peaaegu kõik nimisõnad (sellest tulenevalt ka omadus- ja asesõnad) vene keeles ühte kolmest soolisest grupist: mees-, nais- ja kesksugu. Peab silmas pidama, et mitte alati ei toimu see bioloogilise või sotsiaalse jaotuse järgi, sest vene keeles on sugu ka nendel sõnadel, mis tähistavad elutuid objekte. Kuigi mitmed silmapaistvad keeleteadlased, teiste hulgas ka M. Šeljakin, on arvamusel, et grammatilise soo kategooria väljakujunemise ajaloolisel perioodil tingis ühele või teisele elutule objektile konkreetse soo omistamise ikkagi mingisugune eseme tunnustega seotud assotsiatsioon, ei pruukinud see alati olla semantiline (Šeljakin 2002: 51). A. Aksjonov eristab grammatilise soo motiveeritust ja mittemotiveeritust, elutute objektide sooline kuuluvus on mittemotiveeritud (sest puudub seos grammatilise soo ja eseme olemuse vahel), samal ajal kui elusolendite oma on motiveeritud, kui mõned erandid välja arvata (Aksjonov 1984: 17-18).

Eksisteerib grupp sõnu, mida olenemata oma soolisest kuuluvusest võib kasutada nii naiste kui meeste kohta, kuid nende ühildumisel omadussõnade või tegusõnadega tuleb arvestada siiski sõna sooga. Nende sõnade hulka kuuluvad näiteks sellised meessoost lekseemid: человек 'inimene', ребенок 'laps', подросток 'teismeline', враг 'vaenlane', классик 'klassik' jms. "Kõikides nendes sõnades on sugu neutraliseeritud: need tähistavad isikuid ilma soolise eristamiseta ning ei võimalda süntaktilist naissoo väljendamist (ei saa öelda: ${ }^{\star}$ Человек пришла, isegi kui viitame naissoost isikule) (Šeljakin 2001: 33). Võrdselt naiste ja meeste kohta saab kasutada ka kolme naissoost nimisõna: персона 'persoon', личность 'isiksus', особа 'isik', need sõnad ühilduvad süntaktiliselt omakorda ainult naissooga. 
Lisaks eelpool mainitule on vene keeles mõned sõnad, millel üldse puudub sooline kuuluvus ja mida võib kasutada nii mees- kui naissoost isikute kohta, näiteks: сирота 'orb', пьяница 'joodik', соня 'unimüts, коллега 'kolleeg' jt. Isiku soo konkretiseerimiseks kasutakse vastavast soost omadussõna, näiteks хороший коллега 'hea meeskolleeg' ja хорошая коллега 'hea naiskolleeg'. Sellest hoolimata tuleb tunnistada, et üldise iseloomuga väidetes, kus ei viidata konkreetsele isikule, on ikkagi eelistatud kasutuseks meessoost variant (Nikunlassi 2000: 776). Näiteks: Каждыı̆ сupoma хочет, чтобы у него была большая семья. 'Iga orb tahab, et tal oleks suur perekond'. Üldine tähelepanek on veel see, et sellised sõnad väljendavad sagedamini negatiivseid kui positiivseid omadusi (Vastšenko 1984: 63).

Üldiselt ollakse tänapäeva vene keeleteaduses seisukohal, et lingvistiline meessoo kategooria on markeerimata, "see on seletatav asjaoluga, et paljud professionaalsed tegevusalad ja teised ühiskondlikud valdkonnad olid varem üldiselt meessoost isikute privileegiks, aga pärast teatud ühiskondlikke muutusi hakkas grammatiline meessoo vorm viitama ka naissoost isikutele. Siiski pole alati õigustatud pidev meeste ja naiste vastandamine töö, ühiskondliku tegevuse ja haridusega seotud ametlikes dokumentides. Seetõttu on ametlikus stiilis kinnistunud peamiselt meessoo vormi kasutamine neutraliseeritud funktsioonis" (Šeljakin 2001: 32).

Siiski ei ole ka vene keel ja kultuur jäänud puutumata sellistest ülemaailmsetest nähtustest nagu feminism või meeste ja naiste võrdõiguslikkuse küsimused. Seetõttu on tänapäeva vene keeles laialt levinud võtteks märkida naissugu süntaktiliselt, näiteks: Bpaч пришла, harvemini хорочая врач (Šeljakin 2001: 32). Kõnealune nähtus on tingitud ka veel asjaolust, et sageli on ameteid märkivate nimetuste naissoost vormid markeeritud, kõnekeelsed ja mõnikord negatiivse konnotatsiooniga, näiteks инженерша 'naisinsener', химичка 'naiskeemik', секретарша 'naissoost sekretär'.

Tuleb mainida veel seda, et eelmise sajandi 60. aastatel leidsid mõned keeleteadlased, nende hulgas ka A. Zaliznjak (1967: 80), et tegelikkuses võiks vene keeles eristada isegi veel üht grammatilist sugu, tema kasutas terminit "paarissugu" (vene k nарныци род, 
ing. k pair gender). Põhjuseks oli see, et traditsiooniline nimisõnade vastandumine sookategooria alusel ei võimaldanud hõlmata paraku kõiki nimisõnu. Sõnu, millel puudub ainsuse vorm, mis kuuluvad Pluralia tantum-sõnade hulka, ei eristata grammatilise soo kategooria alusel. Selline olukord näis A. Zaliznjakile aga selgelt vastuolulisena, sest üldine reegel kinnitab, et kõikidel nimisõnadel on üheks tunnuseks grammatiline sugu. ${ }^{24}$ Paarissoo nähtuse aktsepteerimine võimaldaks selle vasturääkivuse likvideerida. Termin kannab sellist nimetust, sest enamjaolt kuuluvad Pluralia tantum -sõnade hulka nimisõnad, mis tähistavad kahest osast koosnevaid objekte, näiteks брюки 'püksid', ножницы 'käärid' jms, kuid mitte ainult, näiteks lekseemid: дрожжи 'pärm', сливки 'koor' ei sisalda sellist tähendust. Siiski peab tõdema, et suurem osa tänapäeva grammatikateatmikke ja õpikuid ning ka keeleteadlasi ei ole seda seisukohta omaks vôtnud ning räägivad vene keele grammatikas siiski vaid kolmest soost.

Nagu juba eelpool öeldud, ei põhjusta vene-eesti tõlke seisukohast elutute objektide grammatiline sugu erilisi raskusi. Käesolevast analüüsist jäävad kõrvale ka leksikaalset sugu väljendavad sõnad nagu мать 'ema', сың 'poeg', nemyx 'kukk' jne, sest viide soole esineb neis enamasti mõlemas vaadeldavas keeles ja seetõttu saab neid tõlkida probleemideta. M. Šeljakin väidab, et loomade nimetused on hoolimata oma grammatilisest soost mittemarkeeritud, need võivad viidata nii looma soole või ka olla üldiseks loomaliigi nimetuseks, selle poolest erinevad need sõnad isikuid tähistavatest nimetustest (Šeljakin 2001: 33).

\section{Venekeelsed asesõnad он/она ja eestikeelne tета}

Pöörame tähelepanu esimesele raskusele: venekeelsed asesõnad $o H /$ она ја eestikeelne tema.

24 Sõnad cupoma (orb) ja пяница (joodik) on üheaegselt nii mees-, kui naissoost sõnad, samal ajal kui sõnal брюкu (püksid) puudub grammatiline sugu sootuks. 
Olgu öeldud, et kuigi eesti keeles eksisteerib sõna temake, kasutatakse seda enamjaolt siiski vaid ilukirjanduses. "Eesti keele seletavas sõnaraamatus" seisab, et vorme temake ja temakene kasutatakse kurameeriva naisisiku kohta, tähenduses 'kallim, pruut' (EKSS 2009). Sellest võib järeldada, et temakest ei saa kasutada kontekstis, kus on vaja viidata lihtsalt naissoost isikule. Tegelikult peab see paika vaid osaliselt, on selge, et üheski ametlikus dokumendis ei saa seda vormi tõesti kasutada, kuid ilukirjandus nii rangeid piiranguid siiski ei kehtesta, kuigi sõna täielikust neutraalsusest ei saa me rääkida muidugi mitte mingil juhul. Näiteks keeletoimetaja Maris Makko on märkinud: "Muidugi, ilukirjanduse tõlkijatele ongi paras pähkel, kuidas eristada tihedas tekstis he'sid ja she'sid, on'e ja ona'sid. Millalgi püüti naistegelase kohta rakendada pisendusliitega moodustatud tuletist "temake", kuid sellel on naeruvääristav varjund.” (Makko 2011).

Näide (1) pakub võimalust võrrelda eri tõlkevariante. Venekeelne tekst pärineb filmist "D’Artagnan ja kolm musketäri”, seal on stseen, kus Rochefort tuleb kardinal Richelieu'le teatama, et kuninganna kohtus Buckinghami hertsogiga, aset leiab järgmine venekeelne dialoog:

(1) Richelieu: Так что же, Рошфор?

Rochefort: Они виделись, Ваше Преосвященство.

Richelieu: Кто это “они”?

Rochefort: Он и она.

Richelieu: Кто это “он и она”?

Rochefort: Королева и герцог.

Meid huvitab selles näites just asesõnade $о н$ ја она kasutamine ning tõlkimine eesti keelde. Artikli autor on kohanud kolme eri tõlkevarianti. Esimene versioon pärineb filmist, mida kunagi näitas Kanal 2. Selles eestikeelses variandis oli tõlkija valinud asesõnad tema ja temake. Kuna vähemalt Alexander Dumas'i teoste kohaselt olid Buckinghami hertsogi ja Prantsusmaa kuninganna vahel romantilised tunded, siis sellesse konteksti võiks sõna temake isegi sobida, eriti kui lähtuda eelpool mainitud "Eesti keele seletava sõnaraamatu" tähendusest. 
Teine tõlkeversioon pärineb firma Video Leader välja antud DVD-lt. Tõlkija on venekeelsed asesõnad eesti keelde pannud sõnadega meesterahvas ja naine. Ka sellele versioonile ei saa midagi ette heita. Artikli autorile näib vaid, et parema kõla saavutamiseks oleks tõlkija võinud eelistada sarnase struktuuriga sõnu, ehk siis mees ja naine või meesterahvas ja naisterahvas.

Kolmanda tõlkeversiooni võib leida firma DVD Sonatiin OÜ toodetud DVD-lt. Selles versioonis on tõlkija otsustanud loobuda venekeelse soolise vastandamise edasiandmisest eesti keeles. Venekeelsed asesõnad tõlgitakse eesti keelde lekseemiga nemad.

Üldiselt tundub, et vormi temake kasutatakse tõlkes kõige vähem (artikli autor ei ole viinud läbi spetsiaalset statistilist uurimust, väide tugineb piiratud hulga tekstide tõlgete analüüsil). Siiski ei saa öelda, et temake oleks tõlkevariandina täiesti kõrvale jäetud. Lisaks vene keelest tõlkimisele pöörduvad tõlkijad selle variandi poole ka näiteks ingliskeelse originaali puhul. Vt näited (2), (3) ja (4).

(2) Если бы Варвара не знала совершенно точно, что в этом кабинете молодой мужик руководит делами огромного холдинга, она бы подумала, что «гнезды шкоржанки» принадлежит ну, скажем, экзальтированной и утонченной содержательнице журнала «Он и Она». (Т. Ustinova)

Kui Varvara poleks kindla peale teadnud, et selles kabinetis juhatab noor meesterahvas suure ettevõtte äriasju, võinuks ta arvata, et "põldrüüdi pesa" kuulub näiteks ajakirja Tema ja Temakese eksalteeritud ja rafineeritud kirjastajale.

(3) Да, да, кино разрешает игру, разрешает легкость... страсть... брызги шампанского... он и она... мужчина и женщина... ночное море... (L. Ulitskaja)

Jaa-jaa, film lubab mängu, lubab kergust... kirge... šampanjapritsmeid... tema ja temake... mees ja naine... öine meri...

(4) The Cook, The Thief, His Wife \& Her Lover (Eesti kultuurisündmuste kalender)

Kokk, varas, tema naine ja temakese armuke 
Analüüsides ilukirjanduslikke tõlkeid, näib üldiselt, et kõige sagedasem tõlkevõte on asendada meessoost asesõna nimisõnadega mees, noormees, poiss ja naissoost vastavalt naine, neiu jne. Mainitud tõlkevõte on igati õigustatud, probleemiks võib see osutuda vaid siis, kui originaali autor ei anna oma tekstis informatsiooni näiteks tegelase vanuse kohta, sellisel juhul võib tõlkijal olla raske otsustada, kas tõlkida näiteks asesõna $o H$ vastega mees, noormees või poiss jne. Vaatleme järgmisi näiteid (5), (6), (7) ja (8), kus asesõnad on tõlgitud nimisõnadega.

(5) Он подошел, поклонился, сел рядом. (B. Akunin) Mees tuli lähemale, kummardus ja istus kõrvaltoolile.

(6) Она успела посидеть не только у себя на постели (именно так, как вообразил Извеков), она двадцать раз перешла с места на место, присаживаясь и опять поднимаясь, подбегая то к двери, то к окну, вслушиваясь в стоны и присвисты вьюги и боясь не отличить от них стук Кирилла. (K. Fedin)

Neiu jõudis veidi istuda oma voodil (just nii, nagu kujutas ette Izvekov), käia kakskümmend korda ühest kohast teise, võtta istet ja tõusta jälle, kord joosta ukse juurde, kord akna juurde, kuulatades teraselt tuisu oigeid ja vilistamisi ning kartes, et ei eralda nendes Kirilli koputust.

(7) - Очень, - честно ответил он, и она соскочила, оставив его стрелу невыпущенной. (L. Ulitskaja)

"Väga meeldid," vastas ta ausalt, ja naine hüppas maha, jättes tema noole välja laskmata.

(8) Я почему-то услышал сейчас ту музыку, и как танцевали двое - он и она, пастух и пастушка. (V. Astafjev)

Miskipärast kuulsin ma praegu toda muusikat, ja kuidas nad kahekesi tantsisid, - tüdruk ja poiss, karjapoissi-karjapiigat meenus talle.

Muidugi ei ole haruldased ka need juhud, kui asesõna tõlgitakse asesõnaga, kuid seda tehakse tavaliselt ikkagi ainult siis, kui kon- 
tekstist on selgelt aru saada, kellele asesõna viitab. Tegelikult on päris sagedased ka need olukorrad, kui tõlkija ühendab tõlkes originaali kaks asesõna (он ја она) üheks sõnaks nemad. Asesõnaga tõlkimist illustreerivad näited (9), (10) ja (11).

(9) Поехала эта Юлия Петровна в горы... Была отличная погода! Впереди едет она со своим проводником, немножко позади - я. Отъехали мы версты три-четыре, вдруг, понимаешь ты, Васичка, Юлия вскрикивает и хватает себя за грудь. Ее татарин хватает ее за талию, иначе бы она с седла свалилась... Я со своим проводником подъезжаю к ней... (A. Tšehhov)

Sõitis see Julia Petrovna mägedesse... Oli oivaline ilm! Ees sõidab tema oma teejuhiga, veidi tagapool - mina. Sõitsime versta kolm-neli eemale, äkki, kas mõistad, Vasjake, Julia karjatab ning võtab endal rinnust kinni. Tema tatarlane haarab tal piha ümbert kinni, muidu oleks ta sadulast maha kukkunud... Mina oma teejuhiga sõidan tema juurde...

(10) Пилат сказал, что он разобрал дело Иешуа Га-Ноцри и утвердил смертный приговор. (M. Bulgakov)

Pilatus ütles, et ta vaatas läbi Ješua Ha-Notsri süüasja ja kinnitas surmaotsuse.

(11) В первое время, когда я в таких случаях вынимал свой редкий рубль, он и она с такой настойчивостью всучивали мне его назад, что вскоре я перестало бращать на это внимание, ибо никчему так быстро не привыкает человек, как к дармовому угощению. (F. Iskander)

Alguses, kui ma sellistel juhtudel oma ainsa rubla välja võtsin, toppisid nad mõlemad selle nii visalt mulle pihku tagasi, et ma varsti seda enam tähelegi ei pannud, sest inimene ei harju mitte millegi muuga nii kiiresti kui tasuta kostitamisega.

Neljas tõlkevõte, mida sellistes eri keelte võimalustest tingitud keerulistes olukordades kasutatakse, on asesõnadele tõlkes vastetena hoopis tegelaste nimede kasutamine, näited (12) ja (13). On selge, 
et sellist strateegiat on võimalik rakendada vaid siis, kui tegelaste nimed on juba teada. Kui autor on otsustanud mingis teksti osas (näiteks teose alguses) oma tegelase jätta anonüümseks ja viidata talle vaid asesõnaga, siis ei ole tõlkijal õigust oma tekstis samas lõigus tegelase nime kasutada ning sellega autori taotlusi hävitada. Peab ütlema, et analüüsitud materjalis ei esinenud sellist tõlkija eksimust kordagi.

(12) - Лежи тихо, - сказал он, и она ничего не поняла.

(T. Ustinova)

"Lama vaikselt," ütles mees ja Varvara ei saanud millestki aru.

(13) - Ты умеешь готовить? - удивился он, и она услышала, как он усмехнулся. (T. Ustinova)

"Sa oskad süüa teha?" imestas Ivan ja Varvara kuulis, kuidas ta muigas.

\section{Venekeelsed asesõnad он/она ja eestikeelne see}

Teine problemaatiline olukord tõlkes on venekeelsed asesõnad он/она ја eestikeelne see. Vene keele grammatilise soo kategooria annab keelele selle eelise, et on võimalik koostada küllaltki pikki lauseid, kus mingisugust eset või nähtust mainitakse nimetusega vaid korra ja edaspidi saab sellest esemest või nähtusest rääkides kasutada vaid vastavast soost asesõna, vt näide (14).

(14) Книга лежит на столе, её подарил мне мой дедушка.

Raamat lebab laual, selle kinkis mulle minu vanaisa.

Vene keeles ei teki mitte mingisugust kahtlust selles osas, et vanaisa kinkis kõnelejale raamatu ja mitte laua, sest sõnad on eri soost ning lause teises pooles on kasutatud naissoost asesõna, mis saab viidata vaid naissoost nimisõnale ehk siis raamatule. Eestikeelses tõlkes ei ole asi aga sugugi nii selge ja üheselt mõistetav, sest asesõna see ei sisalda endas mitte mingisugust viidet sellele, millist sõna asendatakse. Me võime vaid oletada, et vanaisa kingituseks oli raamat. Sellised kontekstid nõuavad tôlkijalt tähelepanelikkust ning sageli 
ei olegi eesti keeles muud lahendust kui eseme või nähtuse nimetuse üle kordamine, parim viis on seda muidugi teha sünonüümse sõnaga, kui selline võimalus eksisteerib.

Keerulisem olukord võib tekkida aga siis, kui juba originaalis pole aru saada, millist nimisõna konkreetne asesõna asendab. Näide (15) pärineb ühest ehitusalasest reklaamitekstist Internetis.

(15) Мы произведём качественный ремонт в доме, стоимость которого вас обрадует.

Me teostame kvaliteetse remondi korteris, mille maksumus rõõmustab teid.

Jääb arusaamatuks, mis täpselt klienti rõõmustama peaks, kas remondi või korteri hind, seda enam, et kõnealune firma pakub nii ehitus- kui ka remonditöid.

\section{Isikuid ja ameteid tähistavad nimisõnad}

Viimane grupp sõnu, mis põhjustavad tõlkes raskusi, on isikuid ja ameteid tähistavad nimisõnad. Õigluse huvides tuleb tunnistada, et ka eesti keeles on siiski mõned võimalused isikute soo väljendamiseks. Tõsi, Kerli Puna märgib oma magistritöös: "Eesti keeles tähendab laulja seda inimest, kes laulab, olenemata tema soost. Hiljem on teistest keeltest laenatud tuletusliidete (tar-liidesoome keelestja nna-liide saksa keelest) abil tekkinud küll võimalus laulja naissoolisust rõhutada ja öelda lauljatar, lauljanna, aga see ei tähenda, et laulja märgiks nüüd ainult meessoost lauljat" (Puna 2006: 11).

Üldiselt võib eesti keeles eristada kolme võimalust soospetsiifiliste sõnade loomiseks, vaatleme neid variante lähemalt.

1. Tuletusliidete -nna, -ss ja -tar abil on võimalik moodustada sõnu, mis tähendavad elukutseid, positsiooni, rahvust jms, näiteks: laulja - lauljanna - lauljatar, õpetaja - ópetajanna, krahv - krahvinna - krahvitar, jumal - jumalanna, parun - paruness, poolakas - poolatar jne. 
Siinkohal tuleb tõlkijal pöörata tähelepanu sellele, kas naissoost isikut väljendav sõna on neutraalne. Selles, et spetsiaalse liitega moodustatud sõna, mis märgib naissugu, on igal juhul markeeritud, on keeleteadlased juba ammu kokkuleppele jõudnud, küsimus on pigem selles, kas konkreetset sõna saab kasutada igal pool ja igas olukorras. Üldiselt näib, et rahvust märkivad sõnad on neutraalsed, keerulisem lugu on aga ameteid tähistavate lekseemidega. Näiteks tundub artikli autorile, et sõna õpetajanna on tänapäevaks juba pisut arhailise kõlaga ja tõenäoliselt me ei kasutaks seda igas kontekstis täiesti neutraalsena.

Analüüsitud materjalis esines ka juhtumeid, kus tõlkes kasutakse harvaesinevaid ja siinkirjutaja hinnangul isegi pisut kunstlikult kõlavaid vorme nagu näiteks (16).

(16) Я решил этосразу, как только она явилась в подотдел и заявила, что она ученица самого N. (Её немедленно назначили заведующей Изо.). (M. Bulgakov)

Ma järeldasin seda kohe, nii kui ta allosakonda ilmus ja teatas, et on N. enda ópilane. (Ta määrati jalamaid Kunsto juhatajannaks.).

2. Eesliite nais- abil: üliópilane - naisüliópilane, sportlane - naissportlane jne.

3. Liitsõnadega: baarmen - baaridaam, toapoiss - toatüdruk, esimees - esinaine, kasuvend-kasuõde jne.

Aga on selge, et sellist soolist eristamist võimaldab suhteliselt väike hulk sõnu. Tõlkija töös tuleb paraku ette palju keerukamaid olukordi, kus parimat ja täpsemat vastet leida on väga raske ning mõnikord lausa võimatu.

Siiani oleme keskendunud sõnadele, millel on mõlemas keeles põhimõtteliselt sugu tähistavad vasted olemas ja mis tõlkimisel raskusi ei põhjusta, v.a juhul, kui ühes keeles on sõna neutraalne, aga teises keeles selgelt markeeritud või isegi negatiivse konnotatsiooniga (halvustava tähendusega sõnade kohta vt allpool). Edasi vaatleme aga juhtumeid, kus tõlkija ei saa ka kõige parema taht- 
mise juures anda sajaprotsendiliselt edasi originaali sisu. Analüüsime kahte B. Akunini venekeelse romaani pealkirja ja nende tõlkeid eesti keelde:

(17) Любовница смерти

Surmaarmuke

Любовник смерти

Surmakallike

Eesti keeles puudub sõnal armuke soolistatus, seda mõistet võib võrdselt kasutada nii mehe kui naise kohta. Näited (19) ja (20) viitavad sellele, et pigem seostub sõna armuke ikkagi naissoost isikuga. Vene keeles aga tähistatakse eri soost armukesi eri sõnadega (любовник - mees ја любовница - naine). Vastavalt Suиrele vene keele seletussõnaraamatule on sõnal любовник kolm tähendust: 1) mees, kellel on abiväline suhe; 2 ) vananenud tähendus: kallim, armunu; 3) teatris armunud noormehe roll, ja sõnal любовницаesimene ja teine tähendus (VKSS 1998). Tõlkijal pole näites (17) kuigi hästi õnnestunud sõna tähendust edasi anda, sest kallike on mõningates sõnaraamatutes märgitud küll kui vananenud sõna armukese kohta, aga on selge, et tänapäeva lugejale vaevalt et enam see tähendus esimesena pähe torkab. Pealegi on sõnal armuke üldiselt halvustav maik, mis sõnal kallike täiesti puudub.

Vaatleme korraks, kuidas on neid pealkirju tõlgitud keeltesse, kus grammatilise soo kategooria eksisteerib (vähemalt asesõnade tasemel):

a) inglise keel: She Lover of Death ja He Lover of Death;

b) saksa keel: Der Magier von Moskau ja Die Liebhaber des Todes;

c) hispaania keel: La amante de la muerte ja El amante de la muerte.

Nagu näha, on saksa keele tõlkija hoolimata oma keele võimalustest otsustanud tõlkida pealkirju hoopis teistmoodi ja loobuda otsesest soolisest vastandamisest. Inglise keele puhul võiks kerkida küsimus, miks ei ole tõlkija kasutanud näiteks sõna mistress, mille üks tähendustest on samuti 'armuke'. Tõenäoliselt on põhjuseks 
see, et tõlkija soovis säilitada teatud paralleeli kahe pealkirja vahel, seetõttu lahendas ta olukorra soole viitavate asesõnadega.

Veel mõnda aega tagasi oli käesoleva artikli autor veendunud, et sõna meesarmuke ei ole eesti keele seisukohast aktsepteeritav, aga selgus, et tegelikult võib seda lekseemi kirjasõnas leida küll, vt näide (18), mis pärineb Eesti Ekspressi kultuurilehest Areen.

(18) Rooma lähedalt leiti keiser Hadrianuse meesarmukese mälestuseks püstitatud templi varemed. (Areen)

Lisaks kõnealusele näitele võib sõna meesarmuke leida ka internetiavarustest. Siinkirjutajale tundub selline vorm siiski liialt kunstlikuna ja ilukirjandusse mitte eriti hästi sobivana ning seetõttu tuleksid võimalike tõlkevariantidena kõne alla hoopis: Surma mõrsja ja Surma peig. Kuigi ka nendel sõnadel puudub armukese negatiivnetähendus, siis saaks sel viisil anda edasi vähemalt soolist erinevust ja kui lähtuda teoste sisust, siis tuleb tõdeda, et käesoleval juhul on oluline tegelaste sooline eristamine juba raamatu pealkirjas.

Analüüsides veel kontekste, kus esinevad koos mõlemad venekeelsed sõnad (любовник ја любовница), võib jõuda küllaltki huvitava tulemuseni. Kuigi sellelaadseid näiteid ei ole palju, ilmneb põnev ja mõnevõrra üllatav tõsiasi. Näited (19) ja (20) võimaldavad jõuda esialgse järelduseni, et sõnaga armuke tõlgitakse pigem naisterahvale viitavat sõna любовниия, samal ajal kui lekseemile любовник leitakse eesti keeles kas neutraalne vaste (mees, munk) või siis koguni positiivse konnotatsiooniga sõna (armsam). Lisaks tõestab seda väidet ka see asjaolu, et kui eelpoolmainitud Rooma keisri armuke oleks olnud naissoost, ei oleks tõenäoliselt peetud vajalikuks seda rõhutada ja kasutada sõna naisarmuke. Seetõttu võib teha järelduse, et naissoost armuke on norm, meessoost aga normist kõrvalekalle ning seetõttu tuleb seda ka eraldi markeerida. Põhjalikumat arutlust normi ja markeerituse/mittemarkeerituse kohta vt Kerli Puna magistritööst (Puna 2006: 9-10). Loomulikult ei saa nende mõningate näidete põhjal teha lõplikke järeldusi, kuid uurimismaterjali edasiseks analüüsiks võib sellest tähelepanekust leida. 
(19) Вы правы, она меня не любит; но никогда не ручайтесь вделах, бывших между мужем и женой или любовником и любовницей. (F. Dostojevski)

Teil on õigus, ta ei armasta mind; kuid kunagi ärge vastutage asjade eest, mis on olnud mehe ja naise või mehe ja armukese vahel.

(20) Любовнику нельзя было отлучаться часто из монастыря своего; любовнице нельзя было посещать кельи своего любовника. (A. Radišš̌ev)

Mungal polnud võimalik sageli oma kloostrist lahkuda; tema armukesel polnud võimalik armsamat kambris külastada.

\section{Negatiivse tähendusega sõnad ja nende tõlkimine}

Lisaks eelpool mainitud olukordadele osutuvad tõlkija jaoks problemaatilisteks sellised olukorrad, kus ka vene keeles pole naissugu märkiv nimisõna täiesti neutraalse tähendusega, näiteks: секретарь - секретарша 'sekretär', врач - врачиха 'naissoost arst'halvustavalt, певеи - певица 'lauljanna' - певичка 'lauljanna'halvustavalt) jms. Halvustav konnotatsioon võib tähendada nii otsest negatiivset suhtumist isikusse, aga ka irooniat, liigset familiaarsust jms. Eri tõlkijad lahendavad need olukorrad omal moel. Üks variant on sõna tähendusvarjundit ignoreerida ja tõlkida see neutraalse vastega, vt näide (21). Teine võimalus on katsuda siiski kuidagi originaalis sisalduvat nüanssi edasi anda, näited (22), (23) ja (24).

(21) Врачиха, как выяснилось, еще не прибыла, и задержанным велели подождать в предбаннике, увешанном душераздирающими плакатами. (J. Lukin)

Nagu selgus, polnud arst veel tulnud ja kinnipeetud said korralduse oodata sauna eesruumis, mille seinad olid täis südantlõhestavaid plakateid. 
(22) Однако врачиха была с характером, живоприбрала Иосифа к рукам и заставила обучиться зубопротезному делу. (А. Rõbakov)

Aga hambatohter oli karakteriga naine, tõmbas Jossifi kärmesti liistule ja sundis proteesiasjandust ära õppima.

(23) - Ты к Потапову поедешь, Володечка? - придушенным голосом спросиламолодая врачиха, которую в отделении называли исключительно Верунчик. (T. Ustinova)

“Kas sa sõidad Potapovi juurde, Volodja?" küsis lämbunud häälel nooruke arst, keda eranditult kõik kutsusid Veruntšikuks.

(24) Может, Лора и устает, бегая по сцене и разевая рот под фонограмму, но с тех пор, как певичка поселилась у нас, остальным хоть вон беги. (D. Dontsova)

Võib-olla väsib Lora tõepoolest laval ringi joostes ja fonogrammi saatel suud ammuli ajades, kuid sellest ajast, kui lauljannake meile elama asus, on kõik ülejäänud valmis kodunt põgenema.

Näites (24) on sõna lauljannake eriti õnnestunud tõlkevaste, sest "nii vene kui eesti keeles väljendavad deminutiivsed sufiksid kõige sagedamini hellitavat tähendust, kuid võivad tekitada ka põlguse konnotatsiooni (барынька - prouakene)" (Külmoja 2003: 29).

\section{Grammatiline sugu saksa-vene tõlkes}

Kuigi käesoleva artikli esmane eesmärk on juhtida tähelepanu raskustele, mis tekivad vene-eesti tõlkes, siis selleks, et mitte kõlada liiga pessimistlikult, tuleks märkida veel seda, et on ka teistsuguseid olukordi. Ei ole väga keeruline leida kontekste, kus hätta jääb näiteks vene keelde tõlkija ja eesti keelega probleeme ei ole. See võib juhtuda siis, kui mõlemasse keelde (s.t eesti ja vene k) tõlgitakse kolmandast keelest, kus on samuti grammatiline sugu olemas.

Vene tõlkepraktikast on teada vähemalt üks väga huvitav juhtum, kus sõnade sooline eristamine osutus nii oluliseks, et mõned 
tõlkijad olid sunnitud originaali täpsest järgimisest täiesti loobuma. Mitmed vene poeedid, teiste hulgas Fjodor Tjuttšev ja Afanassi Fet, tõlkisid kuulsa saksa poeedi Heinrich Heine luuletust "Ein Fichtenbaum steht einsam", kus räägitakse männi ja palmi vahelisest armastusest ning igatsusest teineteise järele. Vene keelde tõlkimisel tekkisid aga mõistetavad raskused, sest saksa keeles on mänd mees- ja palm naissoost sõna, aga vene keeles on mõlemate puude nimetused naissoost (сосна, пальма). Selleks, et luuletuse mõte ei muutuks ja ei tekiks vihjet homoseksuaalsele armastusele, olid tõlkijad sunnitud venekeelses variandis valima hoopis teised puud (tuleb pidada silmas ka seda, et 19. sajandil, mil nad seda luuletust tõlkisid, oli homoseksuaalsuse teema üldiselt tabu). Tjuttševi tõlkes armastab palmi seetõttu seeder (кедp) ja Feti tõlkes tamm $(\partial y \sigma)$. Need suurepärased ja hinnatud vene luuletajate tõlked näitavad, et grammatilise soo väljendamine võib osutuda tähtsamaks kui täpsete sõnaliste vastete leidmine.

Lisaks Tjuttševile ja Fetile on seda luuletust vene keelde tõlkinud veel I. Pavlov, kelle tõlkes on mänd asendatud seedriga, P. Veinberg, kelle tekstis armastab palmi tamm, ning mitmed teised luuletajad. Ainus kuulsatest vene luuletajatest, kes ei lasknud ennast sooküsimusest häirida, oli poeet Mihhail Lermontov, kes jättis luuletusse oma venekeelses variandis alles nii männi kui palmi. Tuntud keeleteadlane Lev Štšerba kirjutas, et Lermontovi palm muudab kardinaalselt luuletuse mõtet, sest kaob ära mehe armastus kauge ja kättesaamatu naise vastu, tugev ning mehine armastus muutub tõlkes kaunihingeliseks unistuseks (Štšerba 1957: 98-99). Ta näeb Heine luuletuses eelkõige võimatut armastust, mis Lermontovi tõlkes transformeerub lihtsalt üksinduse teemaks (Štšerba 1957: 104).

Ei ole vaja rõhutada, et eesti keelde tõlkimisel ei põhjusta saksakeelsete sõnade sugu mitte mingisuguseid takistusi. Eesti keele seisukohast võib palmi järele igatseda mänd või ükskõik milline teine puu.

Siinkohal tasub teha väikene kõrvalpõige ja mainida, et ka suulises tõlkes on eesti keele tõlgi olukord veidi lihtsam oma vene töökeelega kolleegi omast. Olukorras, kus tõlgitakse vene keelest eesti keelde, saab tõlk alati kasutada asesõna tema vastena vene- 
keelsetele lekseemidele $о н$ ја она. Kui aga tõlge toimub eesti-vene suunal ja kõnes kasutatakse vaid asesõna tema, on tõlkija tunduvalt tõsisema probleemi ees, sest vene keel nõuab asesõnade soolist eristamist. Suulise tõlke praktikas on tulnud ette olukordi, kus tõlk on otsustanud ühe või teise asesõna kasuks (sagedamini valitakse meessoost asesõna) ja siis on kõne keskel, mõnikord ka päris lõpus selgunud, et juttu on olnud hoopis teisest soost isikust. Sellises olukorras tuleks tõlgil jääda võimalikult umbmääraseks, ehk siis eelistada võimalusel sõnu, mis ei sisalda endas vihjet inimese soole, näiteks lekseemе человек, персона, личность jne.

\section{Lõpetuseks}

Lähtuvalt toodud näidetest võib eeldada, et grammatilise soo kategooria tekitab raskusi eelkõige tõlkeprotsessis, siis tegelikult põhjustab see kategooria mõningast segadust ka keelesiseselt. Üksikasjadesse laskumata võib tuua ühe näite, et seda väidet kinnitada.

Vene keeles on üks lekseem, mille sooline kuuluvus on juba pikka aega tekitanud diskussioone, selleks sõnaks on кoøe 'kohv'. Oma vormilt sarnaneb see sõna tüüpilise kesksoost sõnaga nagu näiteks поле 'põld', солнце päike'. Aga kuna tegu pole algupäraselt venekeelse sõnaga, vaid see on vene keelde tulnud prantsuse keelest, kus sõna le café on meessoost, siis oligi laenu esialgne kuju

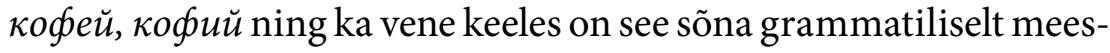
soost. Paraku aga kipuvad nii keeleõppijad kui ka tegelikult emakeele kõnelejad ise selle sõna ühildamisel sageli vigu tegema. Vene keeleteadlane Jelena Remtšukova kirjutab sõna кoøe kohta koguni, et "mittenormikohane kesksugu tõrjub tasapisi välja normatiivse meessoo, sest sõna struktuur sisaldab täishäälikut $o$, misassotsieerub kesksoo lõpuga, samuti tähistab sõna elutut objekti ja need seigad osutuvad tunduvalt tugevamateks mõjufaktoriteks kui meenutus sõna algse soolise kuuluvuse kohta" (Remtšukova 2005: 125). Seepärast on tehtud isegi ettepanekuid lasta selle sõna grammatiline sugu n-ö "vabaks", s.t et omadussõna, mida kõnealuse nimisõnaga koos kasutatakse, võiks olla nii meessoost kui ka kesksoost. 
Keegi keeleteadlane pani ette, et sõna kohv võiks vene keeles olla meessoost, kui tegu on kange ja hea kohviga, ning kesksoost, kui räägime halvast, lahjast ja piimaga kohvist (Remtšukova 2005: 125-126).

Mis puudutab vene-eesti tõlget, siis on jätkuvalt keeruline otsustada, kas grammatiline sugu on tõlkija sõber või vaenlane. Selge on aga see, et kõnealune grammatiline kategooria pakub palju huvitavaid väljakutseid. Tõlkijad võivad end lohutada sellega, et on siiski teatud hulk kontekste, kus grammatilise soo puudumine eesti keeles osutub tõlkeprotsessi lihtsustavaks asjaoluks. Tõenäoline on, et seoses soolise võrdõiguslikkuse teemaga tuleb soolist eristamist ka keelde aina rohkem juurde (kas või uute sõnade kujul) ning võimalik, et ühel päeval on praegused grammatilisest soost tingitud tõlkeraskused muutunud minevikuks.

\section{Allikad $^{25}$}

Akunin, Boris 2005. Surma armuke. Tallinn: Tänapäev.

Akunin, Boris 2005. Surma kallike. Tallinn: Tänapäev.

Astafjev, Viktor 1981. Karjapoissi-karjapiigat: tänapäeva pastoraal. Tallinn: Perioodika.

Bulgakov, Mihhail 1995. Meister ja Margarita. Tallinn: Varrak.

Bulgakov, Mihhail 2004. Saatanlik lugu. Saatuslikud munad. Koera süda. Tallinn: Täna päev.

Dontsova, Darja 2007. Kõõrdsilmsusemikstuur. Tallinn: Ersen.

Dostojevski, Fjodor 1987. Kuritöö ja karistus. Tallinn: Eesti Raamat.

Eesti kultuurisündmuste kalender http://www.kultuur.info/syndmus/ogarditeoo-kokk-varas-tema naine-ja temakese-armuke-15576/ (vaadatud 26.01.2012)

Fedin, Konstantin 1952. Ebatavaline suvi. Tallinn: Eesti Riiklik Kirjastus.

25 Mitmed näited on leitud vene keele rahvuskorpuse (http://www.ruscorpora.ru/) abiga. 
Heine, Heinrich 1985. Gedichte. Berlin: Aufbau-Verlag.

Iskander, Fazil 1978. Õnnelike leidude aeg. Tallinn: Eesti Raamat.

Leiti Rooma homotempel. - Areen 27.11.03, lk B6.

Radištšev, Aleksandr 1958. Reis Peterburist Moskvasse. Tallinn: Eesti Riiklik Kirjastus.

Rõbakov, Anatoli 1983. Raske liiv. Tallinn: Eesti Raamat.

Tšehhov, Anton 2005. Jutustused. Tallinn: Tänapäev.

Ulitskaja, Ljudmilla 2009. Medeia ja tema lapsed. Tallinn: Tänapäev.

Ustinova, Tatjana 2002. Suur kurjus ja väiksemad nurjatused. Tallinn: Ersen.

Ustinova, Tatjana 2006. Eriotstarbega sõbratar. Tallinn: Ersen.

Акунин, Борис. 2001. Любовник смерти. Москва: Захаров.

Акунин, Борис 2001. Любовнииа смерти. Москва: Захаров.

Астафьев, Виктор Петрович 1996. Так хочется жить: повести и рассказы. Москва.

Булгаков, Михаил 1980. Мастер и Маргарита. Рассказы. Москва.

Донцова, Дарья 2004. Микстура от косоглазия. Москва.

Достоевский, Федор Михайлович 1969. Преступление и наказание. Калининград.

Искандер, Фазиль Абдулович 1973. Время счастливых находок: повести и рассказы. Москва.

Лермонтов, Михаил Юрьевич 1988. Сочинения в 2-х томах. Т. 1. Москва. Радищев, Александр Николаевич 1970. Путешествие из Петербурга в Москву. Москва.

Рыбаков, Анатолий Наумович 1982. Тяжелый песок. Москва.

Тютчев, Фёдор Иванович 1966. Лирика. В 2-х томах. Т.2. Издание подготовил К. В. Пигарев. Москва.

Улицкая, Людмила Евгеньевна 1996. Медея и ее дети: повести. Москва.

Устинова, Татьяна Витальевна 2002. Подруга особого назначения. Москва. 
Устинова, Татьяна Витальевна 2006. Большое зло и мелкие пакости. Москва.

Федин,Константин Александрович 1950.Необыкновенное лето. Москва.

Фет, Афанасий Афанасьевич 1901. Полное собрание стихотворений А. А. Фета / под ред. Б.В.Никольского. С.-Петербург.

Чехов, Антон Павлович 1970. Собрание сочинений в восьми томах. Том 3. Москва.

\section{Kirjandus}

Aksjonov 1984 = Аксёнов, Анатолий Тихонович. К проблеме экстралингвистической мотивации грамматической категории рода. - Bonpocbl языкознания № 1. Москва 1984: Наука, с. 14-25.

Deutscher, Guy 2010. Does Your Language Shape How You Think? - The New York Times 26.08.2010. Internetis http://www.nytimes.com/2010/08/29/magazine/29language-t.html?scp=1\&sq=Does\%20Your\%20Language\%20Shape $\% 20$ How\%20You\%20Think?\%20\&st=cse (vaadatud 26.01.2012).

EKSS $2009=$ Eesti keele seletav sõnaraamat . Toim. Margit Langemets, Mai Tiits, Tiia Valdre, Leidi Veskis, Ülle Viks, Piret Voll. Tallinn: Eesti Keele Sihtasutus.

Külmoja 2003 = Кюльмоя Ирина, Вайгла Эда, Соль Майе. Краткий справочник по контрастивной грамматике эстонского и русского языков. Тарту: Tartu Ülikooli Kirjastus.

Lange, Anne 2008. Tõlkimise aabits. Tallinn: Valgus.

Makko, Maris 2011. Mis inimesed? Mehed ja naised! - Eesti Päevaleht 26.05.2011 (vaadatud 26.01.2012).

Nikunlassi Ahti 2000. On gender assignment in Russian. - Gender in Grammar and Cognition, I Approaches to Gender. II Manifestations of Gender. Eds. Barbra Unterbeck (Part I), Matti Rissanen, Terttu Nevalainen, Mirja Saari (Part II). Berlin, New York: Mouton de Gruyter.

Puna, Kerli 2006. Soospetsiifilised isikunimetused sõnaraamatutes ja tekstides. Magistritöö. Tartu Ülikool: Eesti keele õppetool. 
Remtšukova 2005 = Ремчукова, Елена Николаевна. Креативный потенциал русской грамматики. Мосвка: Либроком.

Šeljakin 2001 = Шелякин, Михаил Алексеевич. Функииональная грамматика русского языка. Москва: Русский язык.

Šeljakin 2002 = Шелякин, Михаил Алексеевич. Русский язык. Справочник. Таллинн: Koolibri.

Štšerba 1957 = Щерба, Лев Владимирович. Опыт лингвистического толкования стихотворений. II. «Сосна» Лермонтова в сравнении с её немецким прототипом. - Избранные работы по русскому языку. Москва.

Zaliznjak 1967 = Зализняк, Андрей Анатольевич. Русское именное словоизменение. Москва: Наука.

Vastšenko 1984 = Васченко, Виктор. Грамматическая категория общего рода в русском языке. - Вопросы языкознания № 5. Москва: Наука, с. 60-68.

VKSS 1998 = Кузнецов, Сергей Александрович. Большой толковый словарь русского языка. Российская академия наук, Институт лингвистических исследований. Санкт-Петербург: Норинт.

\section{Summary}

\section{Grammatical gender - translator's friend or enemy?}

Significant differences between languages are always challenges for a translator. The current article analyses difficulties caused by the existence of grammatical gender in Russian and the absence of that category in Estonian. The most difficult contexts for a translator can be divided into three groups:

1) Russian pronouns он (he) and она (she) vs Estonian tema (he or she).

2) Russian pronouns он and она when they refer to objects vs Estonian see (it). 
3) Different nouns that mark professions, nationality, etc.

Estonian language has some means to compensate the absence of the category of grammatical gender:

1) Suffixes: -nna (kuninganna - queen), -tar (lauljatar - female singer).

2) The prefix nais- (naispoliitik - female politician).

3) Compound words, in which one part of the word refers to the sex of the person (kasuode - stepsister and kasuvend - stepbrother).

In Russian each noun is assigned a gender. Russian has three genders: masculine, feminine, and neuter (neutral). In the cases of words like 'father' these relate to physical gender. In the case of other objects like 'pen', 'house', there is no physical meaning attached to the grammatical gender.

A group of words also exists that can refer to either male or female, for example: ребенок 'child', подросток 'teenager', враг 'enemy', персона 'person', etc.

In case of Russian pronouns $\mathrm{OH}$ and она Estonian translator has several options:

1) Replacing Russian pronouns in translation with nouns, such as: man, woman, girl, boy etc. However, it is possible only in the sentences where the person's age is known.

2) Using the pronoun tema in Estonian text, it is important to keep in mind that it can be done only when the reader will not get confused.

3) Referring to the concrete character with his or her name. The translator has to be careful in understanding completely the author's intentions. For example, if the author of the original text wanted to be mysterious and not to reveal the character's name, the translator has no right to do that either.

Comparing Russian pronouns $\mathrm{OH}$ and $о \mathrm{Ha}$ when they refer to objects and Estonian see, it can be said that in Estonian when it is important to distinguish between different objects, in most cases the translator has to repeat the name of the object, since the Estonian pronoun see does not include the meaning of grammatical gender. 
The third group of difficult words for a translator is that denoting professions, nationality, etc. In general, words expressing feminine gender are marked. Nevertheless it seems that lexemes that stand for nationality (эстонка - eestlanna - female Estonian) or status (королева - kuninganna-queen) are more "neutral" than different business titles such as ópetajanna (female teacher). Russian words врачиха, певичка are especially difficult to translate, since in addition to the fact that they refer to female, they also have a negative connotation.

Key words: grammatical gender, Estonian, Russian, translation, pronouns, nouns. 